\title{
An Analysis of the United States Military's Attack on Environmental Laws through Civil Law and Common Law Perspectives
}

\section{Fernando E. Linhares}

\section{INTRODUCTION}

The United States military is among the most powerful forces known to man. It has the capability to destroy human civilization as well as Earth's atmosphere. It has altered civilizations bringing freedom, liberation and democracy to some and causing the demise, exploitation and destruction of others. In advancing this American ${ }^{1}$ agenda its military has caused the deaths of hundreds of thousands and arguably saved the lives of millions. Obviously, the American military costs billions of dollars to maintain, has worldwide operational capacity and is among the largest worldwide polluters and exploiters of the environment. Less analyzed are the many technologies that are derived from military institutions and research laboratories engaged by the Department of Defense which enhance globalization and sustain the Information Age. Even more subtle is the influence that the American military has on American domestic law.

This paper reviews the military's continued efforts to reform existing American environmental law. It argues that even though American legislators created a comprehensive system of regulation regarding the military's impact on the environment, which allowed for military waivers of existing laws, the military desired complete exemption from applicable laws. Such exemption is inconsistent with either the civil law or common law structure of regulation and the democratic system of governance. Moreover, even though the comprehensive development of American environmental statutory law and regulations restrained the need for judicial remedies, and although judicial remedies usually favored the military position, the military continues to seek complete exemption from applicable laws.

1 Although I acknowledge that the United States of America is but one of several countries within the Americas, conciseness dictates that I utilize America when referring to the United States hereinafter. 
Again, common law remedies such as a "balancing of interests" routinely occurs in American courts with respect to cases involving the military, however such "judicial activism" has never compromised the military's operational capacity. Furthermore, even an examination from a civil law perspective, where judges are to simply and strictly apply the applicable legislation or regulation, the existing military waiver right continues to protect the military's operational capacity. Consequently, the American military, a most powerful force, increasingly finds itself outside the framework of regulation and perhaps immune from liability. This impunity may have disastrous consequences.

The resulting impunity on a significant polluter not only endangers the environment but undermines either of the two major legal structures. Both American and Brazilian political systems derive governance from democratically elected legislators and when these legislators exempt a known polluting institution they fail to protect their electorate. Moreover, in the American system, legislation can be further modified by judicial interpretation that has been favorable to the military in past decisions. Nevertheless, the American military continues to seek and gain exemptions from existing environmental laws in a piecemeal manner. ${ }^{2}$ Although there is much concern regarding the marginalized being excluded from the democratic process of both nations, more needs to be written about powerful entities being exempted from the political processes of these nations.

For several years the American Congress remained reluctant to offer environmental immunity and impunity to a significant polluter. Although the military believes that the changing warfare of the $21^{\text {st }}$ century mandates modified training missions there have been no indications of restrictions to these newer training exercises. Obviously, the American military is using the "War on Terrorism" and training concerns as a pretext to receiving unprecedented immunity from environmental regulation. And legislators are acquiescing, neglecting the caution urged by President Dwight $\mathrm{D}$. Eisenhower in examining the growing influence of the "Military Industrial Complex" and its influence on domestic issues. Although, it may be a premature and overstated concern, an unregulated military of such influence and strength is capable of undermining the very system of government they seek to protect and expand.

The American government rests on a system of laws, laws interpreted through the common law structure, a structure which has provided ample protection for military operational capacity. Increasingly, the American military operates outside the norms of law and consequently outside the political process. By Congress legitimizing this position without need, at a time when the Pentagon is undergoing unprecedented restructuring, it endangers the electorate and the democratic system of governance. When the executive branch of

2 Janofsky, Michael, Pentagon is Asking Congress to Loosen Environmental Laws, The New York Times, May 11, 2005. 
government need not be constrained by laws and the judiciary is denied the ability to review, the balance of power is unacceptably shifted toward one entity. Although America has been successful in preventing the concentration of power in one branch of government its "War on Terrorism" has ushered in a new approach to governance which is less democratic and more autocratic. The exemption issue is to environmental law what the Patriot Act is to criminal law, an empowering of the Executive at the expense of the other branches of government. Hopefully America will be able to overcome its concern regarding terrorism without losing its democratic system of governance and the freedoms that militant terrorists sought to take away on September 11, 2001.

\section{AMERICAN COMMON LAW AND BRAZILIAN CIVIL LAW ${ }^{3}$}

\section{A. Common $\mathrm{Law}^{4}$}

Used by nearly forty nations and as a hybrid system in another twenty nations, the Common Law system is the foundation of the American legal system. The Common Law was developed in England and initially served to centralize power in a monarchial government. In 1066, William the Conqueror became king of England and subsequently formed King's Courts which would rule on unsettled disputes throughout his conquered nation. ${ }^{5}$ While these courts tended to rule in a manner that would benefit the king, they developed more independence and a greater reliance on a combination of the utilization of local norms, customs and on decisions of fellow jurists. Such tendencies created a large and persuasive body of law that was used as precedent; meaning matters that have been decided, stare decisis. Since laws were not specifically defined, the Common Law system placed emphasis on procedural matters which further complicated the system. Consequently, the Common Law system is considered more complex than the Civil Law system requiring greater legal education and necessitating more legal practitioners.

The evolution in the increasing use of precedent produced a tradition of judicial independence from the monarchy. Additionally, with the decline of centralized power and ascendancy of representative government, the system of judicial independence was accepted and a stabilized legal system emerged. The American contribution to this predominately

3 "The greatest problem for the human species, the solution of which nature compels him to seek, is that of attaining a civil society which can adninister justice universally" Immanuel Kant, Idea for a Universal History with a Cosmopolitan Purpose, 1784.

4 "Equal and exact justice to all men of whatever state or persuasion, religious or political." Thomas Jefferson, 1801.

5 Fairchild submits that the Common Law system is the most ancient sustained major legal system "[d]uring the fifth century in England, law developed according to decisions made by judges in individual cases, and the Common Law system was born." Fairchild, Erika and Harry R. Dammer, Book, Comparative Criminal Justice Systems, Wadsworth (2001) at page 70. Other scholars date the system with the Magna Carta. 
English development was the creation of Constitutional Law. In 1787, American revolutionaries created a system of laws that set forth the rights of individuals and the limitations on the rights of government. ${ }^{6}$ Moreover, the use of judicial review effectively curtailed the legislative branch from producing legislation contrary to the mandates of the constitution, the superior law. ${ }^{7}$ Consequently, hierarchical systems of courts are necessary to determine a violation of constitutional laws.

The use of Constitutional Law also extended the use of public statutory law tather than case law in defining criminal conduct. This reliance on codified law is distinguishable from the Civil Law system, in that case law continues to provide for the very important and complicated procedural elements associated with Common Law. Indeed, Civil Law countries such as Brazil have developed both a penal process code and a criminal code. While the rulemaking powers of the newly created legislative democracies surpassed those capabilities that were produced by Common Law judges, the judiciary retained the capability to decide if these laws were consistent to the supreme Constitutional Law. Thereby, the separation of power and checks and balances regime survived. Consequently, in America, pure Common Law no longer exists. Legislatures enacted codified law, prevalent in criminal matters, which set forth the elements and prescribes the penalty for the violation. The judiciary continues to decide if such laws are consistent with the constitution. Moreover, the enforcement of laws is performed by the executive branch with the judiciary determining whether constitutional provisions have been followed. Lastly, the role of the judiciary is to determine legal disputes consistent with procedural and evidentiary norms as well as provide legal interpretation. Specific pleading requirements, court rules and rules of evidence provide for the fact-finding process as well as the jury system.

The Common Law functions well in America's individualistic capitalist society. It focuses on past incidents and not on future actions or hypothetical situations. The Constitution provides for the protection of the individual and the Bill of Rights and subsequent Amendments to the Constitution provide for the legislative desires of succeeding generations. The most recent challenge to the due process system is America's concern with terrorism that has prompted legislation such as the Patriot Act and serves as the basis for the military to seek immunity from environmental laws. Arguably, as compared with criminal laws, the development of environmental laws in America created a more comprehensive set of regulations which were popularly supported. Apparently the "bard evidence" presented by environmental scientists was more influential on legislative bodies than the "soft evidence"

${ }^{6}$ The use of charters to dictate the relationship between the king and his subjects was founded by the Magna Carta in 1215. However it only restricted the king in actions towards the nobility. Thereafter, the Petition of Rights of 1628, the English Bill of Rights of 1689 and the Act of Settlement of 1701, provided for additional limited government. The American Bill of Rights enacted in 1791 continues to be among the most expansive documents in regards to individual rights and liberties.

7 Judicial review was decided in Marbury v. Madison, 2 L.Ed. 60, 1803. 
offered by social scientists with respect to criminal justice issues. Moreover, media propaganda routinely focuses on the most recent, more sensational criminal stories than the more complex and comparatively mundane environmental issues. Additionally, the existing media coverage of environmental concerns is often sympathetic to protection issues while criminal reports often focus on enforcement powers. Nevertheless, the current American trend of its governing system supports the exemption issue which weakens environmental protection and supports the Patriot Act which weakens the $4^{\text {th }}$ Amendment's Exclusionary Rule and the judicially created suppression remedy.

\section{B. Civil Law ${ }^{8}$}

The Brazilian political system was formed based on the American political system. There ate three branches of government and a federal and state system of governance. Unlike the American system, Brazil has endured different legal systems based on different constitutions. The most recent is the Brazilian Constitution of 1988, a seventeen year young document. Obviously, the laws under the three hundred years of colonialism or sixty-six years of monarchial rule are invalid. Similarly, the adherence to the multiple Brazilian constitutions since the founding of the Republic in 1889 and their corresponding rule of law has been repeated ignored and violated by the successive authoritarian governments. Consequently, the 1988 Constitution must govern a country that has largely functioned for 488 years under either Portuguese colonialism (1500-1822), a monarchy (1822-1889), an oligarchy (1889-1930) and authoritarian rule (1930-1944 and 1964-1985). A situation vastly different and more complicated than the American political evolution, which from 17761787 essentially moved from English colonialism to a Republic.

Unlike the American political system which essentially relies on two competing political party, the Brazilian political system is comprised of multiple and somewhat viable political parties. Consequently, similar to a parliamentary system these parties must consolidate forces to achieve a majority. These political maneuvers are engaged in under the Civil Law or Continental legal system which relies on codified law and is routinely altered by the political will of the day. The resulting and evolving patchwork of laws is almost unmanageable and promotes circumvention of the legal system. A popular Brazilian phrase used especially when dealing with the legal system or governmental bureaucracy, is "jeito." Brazilians often

" A common Brazilian saying: "To my family and friends everything; to my enemies, the Law."

9 "The proliferation of normative acts, of higher or lower hierarchy, eventually causes a total chaos, for this big mass of juridical laws. As early as 1969 [researchers] already alerted that 'the true legislative labyrinth created as a result of an inflation of statutes passed in recent years has turned the ruling Brazilian law into a patchwork, in which the mere legjslative updating becomes a daily torture for a lawyer and a judge who are searching for the rules applicable to a specific subject, from among acts, supplementary acts, institutional acts, decree-laws and other normative acts." Edilenice Passos, Doing Research in Brazil 2002, at http://www.llrx.com/features/brazil2002.htm. 
use this term to mean 'isn't there a way to get out of this mess.' The use of bribes or favors has been an acceptable practice or 'jeito' in many Latin American Civil Law countries when dealing with public officials. Therefore, it would be expected that a significant informal system of governance would undermine the formal system created by the Civil Law structure..$^{10}$ As a consequence extra-judicial action and vigilantism is more common.

Over 90 nations use the Civil Law system with another twenty using a combined structure with the common law system. Moreover, the Civil Law system is routinely used by Common Law nations to settle disputes over territorial rights. Even England used such laws in the colonization of America due to the limited case law available within its Common Law system. ${ }^{11}$ The Civil Law or Continental legal system dates to the Roman Empire and the Justinian Code published in 533. It also includes the Church produced Cannon Law system, the German Civil Code, and the Napoleonic Code of 1804 and Penal Code of 1810. These laws were particularly important in Europe throughout the $18^{\text {th }}$ and $19^{\text {th }}$ Century nationalistic and revolutionary periods. The Napoleonic criminal code was excessively harsh inasmuch as he "believed in the deterrent effect of severe penalties."12 In Latin America, only Belize maintains a Common Law system while every other country provides for Civil Law or a hybrid system. ${ }^{13}$ Moreover, the American states of Louisiana and Florida have limited influences from the Civil Law system consistent with their experiences with France and Spain, respectively. In Civil Law systems the source of all law is the legislature and elaboration on the law is by the use of additional codes. Judges are analogous to elevated bureaucrats who interpret statutes and apply the law. Their decisions lack the force of precedent and cannot be more influential than the actual statutes. In the rare instance that there is no specific rule of law, the judge's decision will be based on analogy or customary law.

By the time Brazil enacted its Constitution on October 5, 1988, environmental rights was a significant concern. ${ }^{14}$ Consequently, the Brazilian Constitution has a progressive environmental rights focus captured in Chapter 6 , Article 225 of the Constitution. Thereafter, Brazil hosted the Rio Summit in 1992 and passed its own version of the NEPA law in 1997.

10 According to Transparency International's study on public corruption, Brazil ranked fourth of the forty-one countries compared. Eakin, Marhall, Book, Brazil: The Once and Future Country, St. Martin's Griffin, New York (1998) at page 204.

11 Apparently the Civil Law countries of Continental Europe had endured a significant history of territorial warfare which necessitated the creation of codified territorial law.

12 "Post-revolutionary France was going through a period of lawlessness and high crime rates, and the French people were inclined to support a stern criminal code." See Fairchild, supra note 5, at page 50.

1.3 The six hybrid Common/Civil Law countries are: Argentina, Colombia, Guyana, El Salvador, Honduras and Mexico.

${ }_{14}$ Among the greatest environmental champions of the $20^{\text {th }}$ Century was Brazilian Chico Mendez, a labor organizer from the state of Acre who was assassinated on December 22, 1988. Ventura, Zuenir, Book, Chico Mendes: Crime E Castigo, Companhia Das Letras (2003). In 2005, sister Dorothy suffered the same fate in Brazil: extra-judicial action continues. 


\section{NEPA, THE DEPARTMENT OF DEFENSE AND ENVIRONMENTAL LAW $^{15}$}

Congressman John D. Dingell has been characterized as one the "harshest critics" of the military exemption issue. ${ }^{16}$ Congressman Dingell states: "We have fought two World Wars, the Korean War, Vietnam and the Persian Gulf War with this law ${ }^{17}$ in place, and there is no demonstrated need to exempt the Department of Defense now." 18 However, with the exception of the Iraqi, Afghanistan and Persian Gulf Wars and the waning years of the Vietnam conflict, the vast majority of environmental laws post-date the military conflicts set forth by the Congressman. ${ }^{19}$

Moreover, if the military receives a blanket exemption from environmental laws, the possible environmental degradation could be considerable. The Department of Defense [hereinafter DOD] manages more than 425 major military installations located on approximately 25 million acres of federal land which includes habitat for at least 300 endangered species. ${ }^{20}$ Additionally, the Navy operates and trains on oceans and water ways throughout the world. On January 31, 2003, some twenty-seven conservation organizations urged federal agencies to oppose the proposals by the DOD to exempt military activities from key environmental laws. ${ }^{21}$ Specifically, in their correspondence they stated:

Existing laws provide for case-by-case determination to ensure that both military readiness and environmental protection are achieved. Rather than pursue broad legislative or administrative changes, we would encourage the agencies to examine ways to

${ }^{15}$ I believe in the government over corporate interests, the individual over governmental interests and the environment over the individual interest. Paraphrased from the Pelican Brief, Warner Bros. (1993) www.warner.com.

${ }^{16}$ Seelye, Katharine Q, Defense Department Forum Focuses on Environment, The New York Times, Feb. 6, 2003 at A28; other recent stories on the exemption issue include: Greenwire, Military environmental exemptions back in play, May 11, 2005; Eilperin, Juliet, Pentagon seeks waivers on environmental rules, Defense Department cites National Security issues, 'The Washington Post, May 11, 2005, A15; Military environmental exemptions again in play, Environment and Energy Daily - On the Hill, May 11, 2005.

${ }^{17}$ From the newspaper article presumably Congressman Dingell was referring to the Endangered Species Act. However, that law was passed in 1973. The Migratory Bird Treaty Act was passed in 1918, and would consequently cover the eras that the Congressman referenced. In 2005, the Department of Homeland Security has also sought environmental exemptions. Greenwire, Environmental exemption for DHS rides on spending bill, March 16, 2005.

${ }_{18}$ Seelye, The New York Times, supra note 16.

19 The Vietnam conflict essentially ended when the Vietnamese government abdicated on April 21, 1975. Johnson, Paul, Book, Modern Times, Harper \& Row (1983) at page 654. The Persian Gulf War lasted months with Iraq invading Kuwait on August 2, 1990, then signing the cease-fire agreement incorporated in United Nations Security Council Resolution 687, on April 11, 1991. See, Bodansky, Yossef, Book, Bin Laden: The Man who Declared War on America, Random House (2001) at page 29.

${ }^{20}$ High Country News, infra note 24, at pg 2. Specifically, the Army alone "hosts 170 federally endangered species on 94 installations." Seelye, The New York Times, supra note 16; Clark, infra note 99.

${ }^{21}$ Acoustic Ecology, infra note 23, at pg. 7. 
make the existing structure even more effective, such as increasing staffing levels and funding at the permitting agencies and improving inter-agency consultations. ${ }^{22}$

DOD officials have "suggested that the Pentagon should consider reversing its 'past restraint' against having the president invoke national security exemption provisions available in some envitonmental laws." ${ }^{23}$ Apparently, these waivers have never been used. ${ }^{24}$ Professor Stephen Dycus, however, does refer to waivers being used on two occasions, "once in 1980 in connection with the Mariel boat lift, and again in 1999 to protect information about the super-secret Area 51 air base in Nevada." ${ }^{25}$ Interestingly, NEPA law, the cornerstone of American environmental law, does not contain military exemptions but has also never curtailed military operations.

NEPA was enacted in 1969 in order to require federal agencies to consider quality of the human environment in their decision making. ${ }^{26} \mathrm{NEPA}$ is widely considered to be the first act of the modern environmental legislation. ${ }^{27} \mathrm{~A}$ majority of states have enacted their own state environmental policy acts (SEPAs) that require some form of environmental study for state government actions. ${ }^{28}$ NEPA is a unique environmental statute since it is less regulatory, unable to dictate environmental standards or controls. Conversely it emphasizes information: both the documentation of environmental statistics and the dissemination of the documentation. Generally, NEPA establishes policy, sets goals and provides the means for carrying out the policy. ${ }^{29}$

NEPA is a strikingly concise and simply structured federal statute containing a powerful and inspirational purpose clause.

${ }^{22} \mathrm{Id}$.

${ }_{23}$ Acoustic Ecology, Special Report: Military Environmental Exemptions, http://www.acousticecology.org/ srmilitaryenviroexempt.html at pg. 5; Michael J. Bean, an environmental lawyer claims that no defense secretary has ever sought a unilateral exemption from environmental laws. Seelye, The New York Times, supra note 16.

${ }^{24}$ Id.; see also Seelye, The New York Times, supra note 16; High County News, Pentagon lobs bombs at environmental laws, by Laura Paskus, March 31, 2003. "While each of the five [environmental] laws already has provisions that allow military leeway, conservationists point out - and the Pentagon concedes - that none of these exemptions has ever been invoked." Id, http://hcn.org/servlets/hcn.article.

${ }^{25}$ DOD v. ESA et als, infra note 94, at pg. 45. Professor Dycus states that "[a]ll but two of the targeted environmental statutes now provide for case-by-case waivers by the president of secretary of defense for reasons of national security." Id.

${ }^{26}$ Percival, et als, Book, Environmental Regulation: Law, Science, and Policy, Little, Brown \& Co. (1992) at pages 1021-1022. See also Pub. L. No. 91-190, 83 Stat. 852 (1970) (codified as amended at 42 U.S.C. Sections $4321.4370(d))$. The broad policy goals of NEPA are in Section 101, 42 U.S.C. Section 4331 [hereinafter "NEPA"].

27 NEPA pre-dates Earth Day, which was first celebrated on April 22, 1970.

${ }^{28}$ The state acts vary, and some SEPAs may be more encompassing than NEPA, applying to private acts as well as governmental acts.

2940 C.F.R. Sec. 1500.1. 
The purposes of this Act are: To declare a national policy which will encourage productive and enjoyable harmony between man and his environment; to promote efforts which will prevent or eliminate damage to the environment and biosphere and stimulate the health and welfare of man; to enrich the understanding of the ecological systems and natural resources important to the Nation; and to establish a Council on Environmental Quality. ${ }^{30}$

NEPA requires federal agencies to consider the effects of their actions on the environment by preparing a detailed Environmental Impact Statement (EIS). An Environmental A.ssessment (EA), a much less detailed document outlining the proposed federal action and its possible environmental impact, may alleviate the need for an agency to complete a full EIS. ${ }^{31}$ The specific federal agency, the DOD for purposes of this paper, however, does not have to elevate environmental concerns over other considerations. The agency need only consider the environmental consequences of its actions. Once the agency has made a decision, the court may only interject to ensure that environmental consequences were indeed considered, and not to change the decision made by the agency. "Courts apply a 'rule of reason' standard, which assesses 'whether an EIS contains a reasonably thorough discussion of the significant aspects of the probable environmental consequences." 32 Where environmental consequences have been considered, no more is required by NEPA. ${ }^{33}$ Included in the EIS must be a discussion of the alternative proposals to the government action and the environmental impact of each. ${ }^{34}$ Consideration of alternatives is required even if an EIS does not have to be prepared. ${ }^{35}$ The main purpose of the EIS is to inform the public as well as the decision-makers about the proposed action and the alternatives to such action. " $[\mathrm{A}]$ court must make a 'pragmatic judgment whether the EIS's form, content, and preparation foster both informed decision-making and informed public participation."'36

Certain situations exist in which the obligations under NEPA cannot or need not be met by an agency. The most important of these situations for purposes of this paper is that Congress can exempt an agency from having to comply with NEPA duties. Additionally, if an agency's obligations under another statute make it impossible to fully comply with the

${ }^{30} 42$ U.S.C. Sec. 4321, Sec. 2.

${ }^{31} 40$ C.F.R. Sec. 1508.9.

${ }^{32}$ NRDC v. Evans, 232 F. Supp.2d at 1038 (2002), quoting, Churchill County v. Norton 276 F.3d 1060, 1071 (9.th Cir. 2001).

${ }^{33}$ Strycher's Bay Neighborhood Council, Inc. v. Karlen, 100 S. Ct. 497 (1980).

${ }^{34}$ See Percival, Environmental Regulation, supra note 26, at 1067.

${ }^{35}$ Plater, et als, Book, Environmental Law and Policy: Nature, Law, and Society, West Publishing (1992) at pages 632-633.

${ }^{36}$ NRDC v. Evans, 232 F. Supp.2d at 1038 quoting, Churchill County, 276 F.3d at 1071. 
NEPA obligations, NEPA must give way. ${ }^{37}$ Lastly, if the terms of another applicable statute require duties that are "functionally equivalent" to NEPA's duties, the agency may be excused. ${ }^{38}$ These situations, and the overall compliance with NEPA, are subject to judicial review even though NEPA lacks a "citizen suit" provision.

Although NEPA does not provide for a national security exemption, federal courts have refused to review DOD compliance with NEPA when confidential matters regarding national security would be disclosed. ${ }^{39}$ Nevertheless, NEPA claims involving national security are justiciable. ${ }^{40}$ In Weinberger $v$. Catholic Action of Hawaii, the plaintiffs were concerned of possible nuclear storage, and possible exposure, at a new facility constructed by the Navy. ${ }^{41}$ The Navy's regulations prohibited it from either admitting or denying that nuclear weapons were actually stored at the facility. The court had to distinguish between NEPA's role in the decision-making process and the NEPA public disclosure goal. ${ }^{42}$ Essentially the court concluded that when an agency's obligation under another statute makes it impossible to fully comply with NEPA obligations, the federal agency need not comply. ${ }^{43}$ In Weinberger the Navy relied on a FOIA ${ }^{44}$ exemption and that, in conjunction with a Presidential Executive Order, ${ }^{45}$ the Navy was authorized to classify and keep secret in formation that would threaten national security if released. ${ }^{46}$

NEPA cases come to the federal court system under federal question jurisdiction. The courts have taken an active role in ensuring NEPA compliance. ${ }^{47}$ The Supreme Court has held that the decision not to prepare a supplemental EIS is reviewed under the "arbitrary and capricious" standard. ${ }^{48}$ Federal courts may review an agency's decision on whether to prepare an EIS, the adequacy of an EIS, as well as the procedures by which such decisions are made. The usual remedy for a NEPA violation is injunctive relief. However, if Congress

${ }^{37}$ Flint Ridge Dev. Co. v. Scenic Rivers Ass'n of Oklahoma, 426 U.S. 776, 791, rehearing denied, 429 U.S. $875(1976)$.

${ }_{38}$ Western Nebraska Resources Council v. EPA, 943 F.2d 867, 871 ( $8^{\text {th }}$ Cir. 1991).

39 See Plater, Environmental Law, supra note 35, at 653.

${ }^{40} \mathrm{Id}$. at 654 referencing No GWEN Alliance of Lane County, Inc. v.. Aldridge, 841 F.2d 946 ( $9^{\text {th }}$ Cir. 1988) and Romer v. Carlucci, 847 F.2d 445 (8th Cir. 1988). Both cases, however, effectively favored the national security issue by either not requiring the Air Force to prepare an EIS, No Gwen, 841 F.2d at 1386-87, or refusing to allow the Army to explain alternatives in their EIS. Romer, 847 F.2d at 454.

${ }^{41}$ Weinberger v. Catbolic Action of Hawaii, 454 U.S. 139, 144 (1981).

$42 \mathrm{Id}$.

$43 \mathrm{Id}$.

${ }^{44}$ Freedom of Information Act, Exemption 1, 5 U.S.C.A. Sec. 552(b) (1).

45 Executive Order 12065, 3 C.F.R. 190 (1978-1979).

46 Weinberger, 454 U.S. at 144.

${ }^{47}$ See Calvert Cliffs' Coordinating Comm., Inc. v. Atomic Energy Comm'n, 449 F.2d 1109 (D.C. Cir. 1971). In Calvert Cliffs, the court held the agency to strict compliance with the procedural requirements of NEPA.

${ }^{48}$ Marsh v. Oregon Natural Resources Council, 490 U.S. 360 (1989); NRDC v. Evans, 232 F.Supp. 2d at 1037. It is presumed that the same standard of review applies to the decision whether to prepare an EIS; see also Environmental Law, supra note 35, at 636. 
grants the department of defense or any federal agency an exemption from NEPA, the threshold issue on when must an EIS be prepared will be negated and thereby circumventing the environmental protection offered by NEPA. Furthermore, an EIS is only required for "proposals for legislation and other major Federal actions significantly affecting the quality of the human environment." 49 Every phrase in this brief quotation has generated its own case law. ${ }^{50}$ Moreover, the scope of an EIS can be a complex question. This is especially the case when it is unclear whether a federal action is a small, discrete project or a series of actions that should be studied as a whole. ${ }^{51}$ Additionally, the adequacy of the EIS, which generally must include the environmental effects of the proposed action and alternatives to the proposed actions and the alternatives own effects, is subject to evolving case law. ${ }^{52}$

There has been a litany of cases involving environmental groups and the DOD in every area of NEPA. Specifically, a federal court in New York held that a Navy plan to build a battleship at a port and a plan to build housing at the port were not connected because neither was a necessary precondition to the other. ${ }^{53}$ This case underlies that the scope of an EIS is indeed a complex question. The court analysis was based on the $\mathrm{CEQ}^{54}$ and supporting case law which require a finding of a "connected action" as a prerequisite to be considered together in a single EIS. ${ }^{55}$ The DOD was similarly successful in circumventing the application of NEPA when an $8^{\text {th }}$ Circuit Federal Court held that the agency was not required to consider alternate weapons systems when preparing an EIS on an MX missile proposal because that would be outside of the Congressional mandate for the project. ${ }^{56}$ The case specifically addresses the adequacy of the EIS as it relates to the determination of reasonable alternatives.

49 U.S.C. Sec 4332, Sec. 102(2)(C).

5 The Kleppe court discusses when an agency's action becomes a point of being a "proposal." Kleppe $v$. Sierra Club, 427 U.S. 390 (1976); see also 40 C.F.R. Sec. 1508.23. The regulatory definition of "proposal" makes clear that there may be a de facto proposal even if not characterized by the agency as a proposal. Moreover, determining when an action significantly affects the environment has been a most contentious issue under NEPA. See Hanly v. Kleindienst, 471 F.2d 823 (2d Cir. 1972), cert. denied, 412 U.S. 908 (1973); Metropolitan Edison Co. v. People Against Nuclear Energy, 460 U.S. 766 (1983).

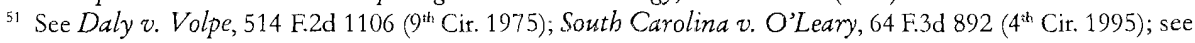
also Environmental Regulation, supra note 26, at 1035-1036 \& 1077; Environmental Law, supra note 35 , at 637 .

52 See Citizens of Burlington, Inc. v. Busey, 938 F.2d 190 (D.C. Cir.) cert. denied, 502 U.S. 994 (1991); North Buckbead Civic Ass'n v. Skinner, 903 F.2d 1533 (11 th Cir. 1990); see also, 40 C.F.R. Sec. 1502.14; NRDC v. Morton, 458 F.2d 827 (D.C. Cir. 1972).

${ }^{53}$ Hudson River Sloop Clearwater, Inc, v. Department of Navy, 836 F.2d 760 (2d Cir. 1988).

${ }^{54}$ NEPA established the Council on Environmental Quality (CEQ) to assist the President with environmental concerns. NEPA, Sec. 105, 42 U.S.C. 4342. The main responsibility of CEQ is to issue guidelines to interpret NEPA's requirements. Although the CEQ Guidelines have no power to alter or stop a federal agency's actions under NEPA, courts owe substantial deference to the CEQ Guidelines interpretation of NEPA. Andrus v. Sierra Club, 442 U.S. 347 (1979).

5540 C.F.R. Sec. 1508.25 (a); see also Thomas v. Peterson, 753 F.2d 754 (9 $9^{\text {th }}$ Cir. 1985).

56 Romer, 847 F.2d 445 (8 $8^{\text {th }}$ Cir. 1988). 
The DOD has had little, if any, interaction with NEPA's international application. NEPA is generally not considered to be applicable to federal actions abroad or those that have significant extraterritorial effects. Presidential Executive Order 12114, however, imposes somewhat similar requirements to those of NEPA on federal actions that have significant environmental effects abroad. The coverage of the Executive Order is more limited than NEPA and private citizens may not sue to compel compliance. Moreover, the presumption against extraterritorial application of NEPA has been held not to apply when the conduct takes place primarily within America and the effects are felt in Antarctica, a continent without a sovereign. ${ }^{57} \mathrm{NEPA}$, however, "can ... be categorized as a remarkable, internationallypioneering declaration of a national policy of environmental sensitivity." ${ }^{58}$ The NEPA model has been adopted by a variety of countries throughout the world including Brazil in 1997.59

In a comparison of the European Community's efforts at creating the EIS system, it is noted that while NEPA does not exclude national defense activities from its application the European Community does. ${ }^{60}$ NEPA will, however do the following:

Make public disclosure of NEPA documents subordinate to the public release rules of the FOIA. While NEPA documentation for classified military projects can be kept secret, the environmental assessment must still be performed. That documentation is subject to in camera review, as provided by the FOIA. While some national defense environmental assessment information can be denied to the public under NEPA the European Community Directive does not provide a blanket exemption. ${ }^{61}$

\section{RECENT CASE LAW: NRDC v. Evans ${ }^{62}$}

Separate from proposed legislative and other DOD initiatives, the Bush administration has advanced a unique interpretation of NEPA's applicability. Despite administrative and judicial interpretations, which have considered EISs to be necessary for projects on all the world's oceans, the Bush Justice Department has argued the NEPA only applies within the 3mile territorial limit. This argument surfaced during the summer of $2002 .^{63}$

${ }^{57}$ EDF v. Massey, 986 F.2d 528 (D.C. Cir. 1993).

${ }^{58}$ See Plater, Environmental Law, supra note 35, at 600.

59 Id.

${ }^{60}$ Wilcox, William, Access to Environmental Information in the United States and the United Kingdom, 23 Loy. L.A. Int'l \& Comp. L. Rev. 121, 183 (March 2001).

${ }^{61}$ Id. citing to NEPA, 42 U.S.C. Sec. 4332(2)(c); FOIA, 5 U.S.C. Sec. 552(a)(4)(B).

${ }^{62}$ See NRDC v. Evans, 232 F.Supp. 2 d 1003 (N.D. Cal. 2002); see also NRDC v. Evans, 168 F. Supp. $2 d 1149$ (N.D. Cal. 2002) granting partial summary judgment to plaintiffs; NRDC v Evans, 2003 WL 220458 (N.D. Cal. 2003) denying plaintiffs' motion on remedy.

63 Acoustic Ecology, Exempting the Military from Environmental Regulations, 2003, http:// www.acousticecology.org. 
In Evans, the plaintiffs sought a preliminary injunction against the "Navy's peacetime use of a low frequency sonar system for training, testing and routine operations." ${ }^{64}$ The plaintiffs asserted that "the EIS was arbitrary and capricious in four respects: (1) failure to consider reasonable alternatives; (2) failure to consider reasonably foreseeable environmental impacts; (3) failure to supplement the EIS ...; and (4) reliance on a white paper not subject to public comment." ${ }^{\prime 65}$ The defendant asserted that they fully complied with NEPA and any other applicable law and taised national security concerns. ${ }^{66}$ The court concluded that the plaintiffs were entitled to a preliminary injunction because plaintiffs had shown a likelihood of irreparable injury and future violations of environmental laws are likely. ${ }^{67}$ Due to national security concerns, however, the court concluded "that a carefully tailored preliminary injunction should issue, which permits the use of LFA sonar for testing and training in a variety of ocean conditions, but provides additional safeguards to reduce the risk to marine mammals and endangered species." 68

This Evans court fully discussed NEPA and its application to matters of national security ${ }^{69}$ The initial plaintiff assertion that the EIS was arbitrary and capricious is based on the defendant neglecting to properly consider all reasonable alternatives which would allow deployment of sonar in a manner consistent with NEPA. ${ }^{70}$ While the absolute number of alternatives that the Navy considered was a concern it was not the controlling factor; instead the court was persuaded that additional alternatives should have been considered. ${ }^{11}$ In fact, there were three alternatives considered by the Navy's EIS: (1) a No Action alternative; (2) full deployment with no mitigation or monitoring alternative; and (3) the Navy's preferred alternative. ${ }^{72}$

The court found that the Navy acted reasonably in rejecting the no-action alternative on the ground that it would not meet the purpose and need of the proposed project. "The No Action alternative is plainly inconsistent with the project's overarching purpose and need to improve U.S. detection of quieter and hard-to-find submarines at long range."'73 Subsequently, the DOD continued to seek legislative amendments to the Marine Mammal Protection Act (MMPA) regarding the definition of harassment so that it may expand the use of low frequency sonar without "harassment" of marine mammals. ${ }^{74}$ According to the DOD, a definitional change in the MMPA "would have a direct impact on the Navy's ability to employ sonat that detects quiet diesel submarines used by countries such as Iran and North Korea."

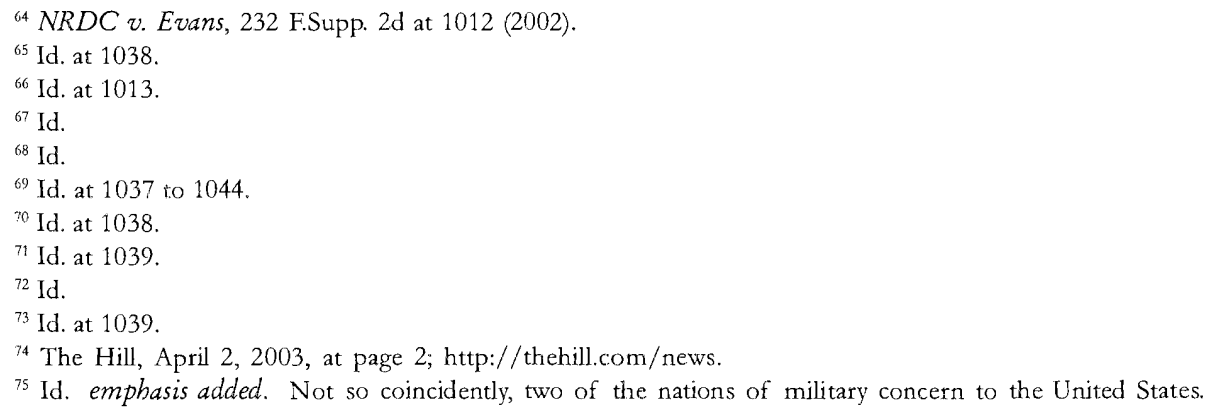


Therefore, the defendant argued it had to consider between the remaining two alternatives offered by the Navy's EIS. The plaintiffs disagreed, arguing that essentially there was only one alternative remaining and that was alternative number three, the Navy's preferred alternative, since the second alternative was "per se" illegal, lacking any mitigation under NEPA or the MMPA. ${ }^{76}$ The court agreed with the plaintiffs, holding that the "plaintiffs have shown a likelihood of establishing that defendants acted arbitrarily in only considering in effect one alternative-the chosen one-and not considering a feasible alternative excluding more, but not all, areas of high marine mammal concentration, while preserving the ability to train in a variety of conditions." 77 Thusly, the plaintiffs succeeded in forcing the Navy to at least consider one other EIS alternative, that is, "the alternative of training only in areas of low marine mammal abundance and biological productivity."78

The second plaintiff assertion that the EIS was arbitrary and capricious is based on the plaintiffs' contention that 'Navy has not considered all 'reasonably foreseeable significant adverse impacts,' and failed to use 'theoretical approaches or research methods generally accepted in the scientific community.",79 The defendant countered that their EIS was prepared after reliance on sound scientific studies by a consensus of qualified scientists. ${ }^{80}$ The court agreed with the defendant holding that although more research would be desirable, "the agency did not act arbitrarily and capriciously." must be at its most deferential" when reviewing agency predictions which are "at the frontiers of science." 82

The third claim of an improper EIS is based on the Navy's refusal to supplement the EIS. The court set forth the necessity for a supplemental EIS (SEIS) which "is required when there "are significant new circumstances or information relevant to environmental concerns and bearing on the proposed action or its impacts." 83 The plaintiffs contend that a certain stranding which occurred in March 2000 in the Bahamas should have been the trigger for the SEIS. ${ }^{84}$ The defendant counter that they did take a "hard look" by briefly discussing the issue in the EIS and in a July 16, 2002 final rule, concluding that the March 1516,2000 , Bahamas sonar exercise were the most plausible source of acoustic or impulse trauma to six beached whales. Nevertheless, even though the court raised concern regarding the contributing factor on sonar use to the strandings, the court found that "[ [b]ecause

${ }^{76}$ NRDC v. Evans, 232 F.Supp. 2d at 1039.

${ }^{77}$ Id. at 1041.

${ }_{78}^{7 d}$ at at 1040 , emphasis in the original.

70 $\underline{\text { Id. at }}$ 1041-1042.

${ }^{80}$ Id. at 1042 .

${ }^{81} \mathrm{Id}$.

${ }^{82} \underline{I d}$.

${ }^{83}$ Id. at 1042 , quoting 40 C.F.R. Sec. 1502.9(c)(1)(ii).

${ }^{84} \mathrm{Id}$. Whales from at least three different species beached themselves in the Bahamas. In December 2001, the Navy published a report on this event. 
analysis of these factual issues requires a high level of technical expertise, [the court] must defer to the informed discretion of the responsible federal agencies.' ... While reasonable minds may differ on the significance of the Bahamas stranding to the use of LFA sonar, plaintiffs have not shown that they are likely to prevail in establishing that defendants' decision not to prepare the SEIS was arbitrary or capricious." 85

The fourth and final claim of an improper EIS is based on the defendant's reliance on unpublished "white paper" not subject to public comment. This "white paper" issue involves the Navy retaining experts to write on the subject sonar, in the wake of the Bahamas stranding, on the cause of non-auditory or tissue damage. ${ }^{86}$ The court found that the white paper merely supplemented existing data, consequently, plaintiffs failed to show arbittary and capricious conduct.

The court concluded that the plaintiffs had satisfied the elements needed for a prelirninary injunction, the "combination of probable success on the merits and a possibility of irreparable injury." ${ }^{\text {"87 }}$ The court then discussed balancing the interests of both the plaintiffs' stewardship of the world's oceans and the defendants' national security concerns. All parties agreed that the preliminary injunction would only apply to the peacetime use of the subject sonar." "Plaintiffs correctly point out that a preliminary injunction would not interfere with the Navy's ability to use LFA sonar during war or in response to imminent threat." ${ }^{89}$ Consequently, the court's only actual limitation on the Navy's utilization of the sonar was to restrict "the sonar's use in additional areas that are particularly rich in marine life, while still allowing the Navy to use this technology for testing and training in a variety of oceanic conditions." ${ }^{.90}$ Furthermore, with the expansion of the "War on Terrorism" and stateless conflict, the answer to whether America is in a continual imminent threat is a very subjective decision.

In August of 2003, a final ruling in Evans slightly favored the plaintiffs. The judge ruled that "if LFA sonar is operated in areas that [endangered species] frequent and the main environment that supports the existence of these species will be irreparably hatmed." 11 However, in October of 2003, the parties negotiated an agreement which limited the new sonar to the seas surrounding North Korea and China. ${ }^{92}$ Additionally, the military retains the ability to use LFA sonar anywhere during war or in response to an imminent threat. Hardly restrictive under the pervasive imminent threat maintained in America since September 11, 2001.

${ }^{85}$ Id. at 1044, quoting Laguna Greenbelt, Inc. v. U.S. Dept. of Transportation, 42 F.3d at 530.

${ }^{86}$ Id.

${ }^{87}$ Id. at 1053.

${ }^{88} \mathrm{Id}$.

89 Id. at 1054.

90. Id. emphasis added.

${ }^{1}$ NRDC v. Evans, August 26, 2003 court order. A newly minted law journal, yet to be accessible by internet or hard copy, summarizes the Evans cases: Morgera, E., Casenote: Natural Resources Defense Council v. Evans (2004), International Fisheries Law and Policy Review, Vol. 1, Issue 1 (2004), which should be available in late May 2005.

92 Id., an NRDC v. Evans, October, 14, 2003 negotiated agreement. www.hsus.org. 


\section{DISCUSSION}

The Evans case could be claimed a victory for the conservationist plaintiffs who gained their preliminary injunction utilizing the Common Law structure. They were able to utilize existing precedents, statutory laws and regulations to have the judiciary uphold the rule of law. However, the decision could also be declared a victory for the defendants since they can continue to use the subject sonar with minimal restrictions. Nevertheless, it probably will be declared something far more sensational. 'Court blockage of crucial Navy device strengthens North Korea's military position" ${ }^{93}$ or 'Court allows Pentagon to kill whales while testing unproven sonar device' are much more interesting headlines and talking-points than 'Court allows for limited use of low frequency sonar despite possible environmental damage.' Consequently, the ability of to curtail military operations has been minimal under existing Common Law structures. However, it is non-existent under the exemption from legislation proposals.

With the continuation of American involvement in Iraq and the continuation of the "War on Terrorism" the Bush administration has significant clout and the desire to limit the application of environmental laws to military operations. Proposed changes have been repeatedly submitted by the Bush administration to the Endangered Species Act, Migratory Bird Treaty Act, Marine Mammal Protection Act, Comprehensive Environmental Response, Compensation, and Liability Act, Resource Conservation and Recovery Act, Clean Air Act, Clean Water Act, and National Environmental Policy Act as those laws apply to certain activities of the DOD. ${ }^{94}$ Notably, eleven of twelve major environmental statutes reviewed for purposes of military exemptions contain some form of waiver for emergency or national security reasons. ${ }^{95}$ Solely the Marine Mammal Protection Act does not contain a provision for waiver or exemption. Perhaps this aspect underscores the reason why the DOD continues to identify this statute for definitional modification exclusively on the term "harassment." While Congress rejected most of the military's requests for changes in environmental laws in 2002, in 2003 "legislators did approve a temporary waiver in a law protecting migratory birds and eased tequirements for land conservation and transfers of surplus property." ${ }^{\prime 96}$ The Bush administration began its push for these exemptions in 2002 and Congress is increasingly approving such exemptions. ${ }^{97}$

9.3 Indeed, a March 21, 2003, article from the DOD states: "The 1972 Marine Mammal Protection Act has been used in third-party lawsuits to stop the deployment of low-frequency sonar the Navy uses to track quiet diesel submarines." Defense Link, infra note 112, pg 2, emphasis added.

${ }_{94}$ DOD v. ESA, et al., The Environmental Forum, Volume 19, Number 5, September-October 2002 at 40.

95 Appendix 1, compiled from www.amc.army.mil/amc/command.

${ }_{96}$ Environmental News Network, Pentagon chiefs told to prepare national security exemptions to environmental laws, by John Heilprin, March 21, 2003, http://www.enn.com/news.

97 USA Today, Military presses to exempt millions of acres from environmental lawe, October 14, 2004, at page 9. The author notes that exemptions have been given for training missions regarding the ESA, sea missions regarding the MMPA, disposal issues involving RCRA, cleanup issues regarding CERCLA and air issues affecting the CAA. See also, Barringer, Felicity, Pentagon is pressing to bypass environmental lawes for war games and arms testing, The New York Times, December 28, 2004, Vol. 154, Issue 53077, pg A18. 
There is broad opposition to a blanket military exemption from environmental laws. ${ }^{98}$ Many of those opposed refer to an April 2002 poll which found that " $85 \%$ of registered voters believe that government agencies such as the Department of Defense should have to follow the same environmental laws as everyone else." refer to over 100 members of the House of Representatives and the nation's largest environmental groups opposing such military exemptions. ${ }^{100}$ Additionally, opponents rely on the findings of a June 2002 General Accounting Office report to support their position. "The GAO found that DOD's own reports indicate that readiness is high for most units across the armed services and do not reflect any significant impacts by environmental laws." ${ }^{101}$

Some opponents of limiting DOD exemptions to major environmental statutes want the exact opposite to occur. On June 13, 2001, Representative Bob Filner (D-Cal.) introduced legislation entitled "The Military Environmental Responsibility Act" (MERA). ${ }^{102}$ The aim of MERA was to "entirely waive any and all sovereign immunity under federal law due to the DOD being "environmentally unaccountable for the last several decades." 103 This law was not enacted and is perhaps a purely political effort but Congressman Filner notes "there is no greater national security interest or mission than the health and safety of our communities." 104 Moreover, this threat to the health and safety of communities will worsen with the major restructuring proposed in May of 2005 by the Pentagon. Any exemption from resulting cleanup tesponsibilities and any exemption regarding disposal of hazardous waste affecting millions of acres is significant by any standard. ${ }^{105}$

The Pentagon seeks to close some 180 installations involving 33 major bases of operation and 800 total facilities. ${ }^{106}$ Since 1988 , near the end of the Cold War and prior to the 1991 collapse of the Soviet Empire, the Pentagon commenced the restructuring of the vast military development that had contributed to the demise of the Soviet Union. The 2005 restructuring plan is the most significant of the four prior plans which occurred in 1988, 1991, 1993 and 1995. The 2005 plan submitted to the Base Realignment and Closure Commission, a governing body that has approved $85 \%$ of past closures, exceeds all prior

${ }^{98}$ The Human Society of the United States, DOD Wants to Duck Environmental and Animal Protection Lawes, http://www.hsus.org.ace/14419; DOD v. ESA, et als, supra note 94, at pg. 42. Mary Beth Beetham, Director of Legislative Affairs, Defenders of Wildlife, opines that "[t]hese exemptions are extremely controversial, are unnecessary, and will have serious consequences for the protection of our nation's environment." Id.

${ }^{99}$ Id.; Clark, Jamie Rappaport, Hearing on RRPI, July 9, 2002, http://www.senate.gov.

${ }^{100} \mathrm{Id}$.

${ }^{101}$ Id.; Clark, Jamie Rappaport, Hearing on RRPI, July 9, 2002, http://www.senate.gov.

102 Army Lawyer, December 2001, at pg 29.

${ }^{103} \mathrm{Id}$.

${ }^{104}$ Congressman Bob Filner, National Security Also Means Environmental Protection, February 4, 2002, http://www truthout.org/docs.

${ }^{105}$ Schmitt, Eric, Pentagon Seeks to Shut Dozens of Bases Across Nation, The New York Times, May 14, 2005. ${ }^{106}$ Id. 
restructuring efforts. Its affect will be felt throughout America with nearly $\$ 50$ billion being saved over 20 years. Moreover, of the nearly 700,000 civilian military jobs, 18,000 will be cut and 67,000 will be removed. The DOD believes that this leaner and more agile force is consistent with defeating the stateless terrorism threat of the $21^{\text {st }}$ Century ${ }^{107}$ However, the restructuring plan may prove to be inconsistent with environmental laws, thereby increasing the desire for DOD to obtain environmental exemptions.

Most opponents object to providing exemptions to the DOD since this "would eliminate DOD's incentive to devise creative solutions wcrking in tandem with experts at the environmental agencies and with the public." ${ }^{108}$ The need and challenge of balancing environmental protections and military readiness will continue despite any exemption right. However, whatever cooperation remains among the disputants to military involvement with environmental laws will be worsened since proper overview and incentives would be negated under a blanket exemption policy.

The supporters of military exemptions opine that environmental exemptions will be limited in scope. Specifically, Raymond F. Dubois states:

This readiness initiative is narrow in scope, addressing only military-unique activities - the training, testing, and operations that relate directly to combat. It does not affect the wide range of DOD activities that do not directly relate to combat, such as our waste-water treatment plants, dry cleaners, construction sites, paint shops or routine transportation. And it does not affect our cleanup responsibilities at closed bases, or bases that might close in the future. Thus, our initiative does not affect those DOD activities of greatest interest to state and federal regulators. ${ }^{109}$

The original proposal for comprehensive military exemptions occurred in April 2002 with the consideration of the Readiness and Range Preservation Initiative (RRPI), part of the National Defense Authorization Act. ${ }^{110}$ Then the RRPI sought to exempt the DOD from provisions of six environmental laws. ${ }^{111}$ DOD success was limited to "a temporary exemption to the Migratory Bird Treaty Act that allowed the 'incidental taking' of endangered birds during bombing and other training on military lands." ${ }^{.12}$ With the inability to pass any of the major exemptions embedded in reauthorization statutes during the 2002

\footnotetext{
${ }^{107}$ See, Govexec.com.

${ }^{108}$ Clark, Jamie Rappaport, Hearing on RRPI, July 9, 2002, http://www.senate.gov.

${ }^{109}$ DOD v. ESA, et als, supra note 94 , at 43.

${ }^{110}$ The Humane Society, supra note 98.

${ }^{111}$ Clark, Jamie Rappaport, Hearing on RRPI, July 9, 2002, http://www.senate.gov.

${ }^{112}$ Defense Link, Pentagon seeks clarity in environmental lawes affecting ranges, by Sgt. $1^{\text {st }}$ Class Doug Sample, March 21, 2003, http://www.defenselink.mil/news.
} 
Congressional year, the DOD has been approaching the exemption issue in a piecemeal manner, such as the proposal on the definitional change in "harassment" as part of the MMPA. ${ }^{113}$ This long-range DOD plan would accomplish the exemption goal by focusing on "a few specific laws this year, with hopes of expanding their exemptions in years to come. In May of 2003, the Pentagon had introduced identical language for weakening the MMPA and allowing the Secretary of Defense to issue blanket exemptions, into three separate pieces of legislation." "14 In 2003, the Pentagon secured military exemptions to the MMPA as well as the Endangered Species Act and the Migratory Bird Treaty Act. ${ }^{115}$ In 2003 the Pentagon was supported as follows: " $[\mathrm{t}]$ he federal Office of Management and Budget has already approved the Pentagon's proposal for exemptions from five laws and submitted it to Congress for inclusion in the Fiscal Year 2004 Defense Authorization Bill."116

Notably, the DOD has incorporated concern for environmental issues in their military readiness operations, such as using environmentally sensitive areas as "false-off limit" mine areas. They also have spent " $\$ 4$ billion each year on efforts to comply with laws and work with civilian agencies, such as the Fish and Wildlife Service that determine how to protect endangered species." 117 Most concerning may be the military's new weapon systems, revised tactics and modern doctrine for military readiness that require the utilization of more land. ${ }^{118}$

New, more powerful weapon systems and changes in war fighting that call for protecting forces over larger areas require more training space then ever before. In 1988, the Army was designed to fight in battalions that would have included 4,000 soldiers and 350 combat vehicles, whereas today's premier fighting units are combat brigade strike teams with 5,000 soldiers and 418 vehicles. At the same time the units have grown, so has the power and the range of the Army's weapons. Ground vehicle speeds have doubled over the past two decades and ammunition fires rates have increased twenty fold since $1981 .{ }^{119}$

${ }^{113}$ Inside Energy, Group expects push for changes to aid offshore firms, January 6, 2003.

${ }^{114}$ Acoustic Ecology, Exempting the Military from Environmental Regulations, http://acousticecology.org. The legislation includes the MMPA, Defense Authorization Act, and the new "Defense Transformation for the $21^{\text {st }}$ Century Act." Id.

115 Id. at pg. 3. In 2002 the military did gain a Migratory Bird Treaty Act exemption for possible shelling of nesting sites, they are now seeking a complete exemption. Id.

${ }^{116}$ High County News, supra note 24.

${ }^{117}$ Government Executive Magazine, Green Troops, October 1, 2002, at page 4, http://www.govexec.com.; "The DOD protects more endangered species per acre than any other federal agency." DOD v. ESA, et als, supra note 94 , at 46.

${ }^{118}$ Id. at page 8.9.

${ }^{119}$ Id.; Presumably, a typical modern Army brigade that is training for realistic warfare uses a 50 by 100 kilometer area, in contrast to a World War II brigade "required a battlefield of 8 by 12 kilometers to train and operate effectively." Durant, infra note 120. 
The higher performance weapons which possess greater maneuverability, stealth and lethality "are typically louder, require more space and fuel for maneuvering, fly lower to the ground or damage it more because of [its increased] weight, and emit more pollutants." ${ }^{\prime 20}$ The utilization of these weapons and the changes in the sheer human size of warfare is occurring "precisely at a time when urban development, sprawl, and commercial competition for airspace are expanding near many of the military's training areas." 121

\section{CONCLUSION}

Former Deputy Defense Secretary Wolfowitz, now head of the World Bank, stated that "National security and environmental security are mutually reinforcing." 122 He further stated that " $[t]$ he challenge is nothing less than supporting the twin imperatives of producing the besttrained military force in the world and providing the best environmental stewardship."123 Furthermore, Environmental Protection Agency officials have stated: "There is not a training mission anywhere in the country that is being held up or not taking place because of an environmental regulation." ${ }^{24}$ The DOD and EPA should abide by their own statements. The attacks of September 11,2001, and increased concerns regarding terrorism have directly curtailed individual rights and may even curtail environmental protections. However, these concerns do not necessitate an unprecedented environmental immunity for the military.

Pentagon officials are requesting broad exemptions from some of our nation's most essential environmental laws without utilizing existing mechanisms to resolve perceived clashes. Rather than requesting broad statutory exemptions, the military should continue to address any perceived problem on a case-by-case basis, working with relevant federal agencies and other stakeholders. Increasing the use of existing waivers, not receiving unilateral exemptions, should be the proper process. I submit that the following summary correctly balances our need for national security and environmental security:

Environmental groups preferred that exemptions were sought case by case because it would force the military to prove its argument. 'No one wants to interfere with training, but we're not persuaded that, except in one or two cases, it really is....

${ }^{120}$ Public Administration Review, Whither environmental security in the post-September $11^{\text {th }}$ era? Assessing the legal, organizational, and policy challenges for the national security state, by Robert F. Durant, Sept. 2002, http://proquest.umi.com.

${ }^{121} \mathrm{Id}$.

${ }^{122}$ Seelye, The New York Times, supra note 16. Barringer, Felicity, Pentagon is pressing to bypass environmental laws for war games and arms testing, The New York Times, December 28, 2004, Section A, pg 18. The Barringer story discusses two lawsuits involving the military at Vieques Islands in Puerto Rico and Fort Richardson in Alaska..

${ }^{123} \mathrm{Id}$.

${ }^{124}$ Government Executive Magazine, Despite concerns, EPA backs enviro exemption for Defense Department, by John Stanton, April 1, 2003. www.govexec.com. 
'Our fear is that if they get an exemption here, what would prevent, say, the Forest Service, which wants to log everything in site in the national forests from getting their exemption? ? $^{125}$

The DOD has effectively used the military to protect our national security, at least in the short term. However, the rationale that "might makes right" is surely short-sighted. Pentagon officials must temember that the importance of protecting our national security rests not only in protecting the military, but in protecting individual liberties and environmental rights. By doing so, by protecting the most vulnerable parts of our society, protecting our national security becomes that much more valuable. NEPA and several other environmental statutes already have all the flexibility needed to protect both our national security and our natural interests. Additionally, the judicial process has, thus far, kept the balance between national security and environmental security.

An additional area of concern is the unprecedented military restructuring and existing human encroachment on DOD installations. ${ }^{126}$ With the growth and expansion of private developmental projects, the open areas controlled by federal agencies, specifically those ateas managed by the DOD, have become the last remaining habitat for wildlife. Similarly, the human encroachment issue affects military readiness since training with explosives and noise concerns are commonplace. Several military installations have allowed their host communities to build roads crossing military land for the convenience of civilian residents. The military "for sound reasons usually wants to accommodate the needs of the local community to the extent possible." 127 However, this sprawl issue adds to the possible encroachment effects of endangered species. State and local of ficials must assist the DOD in managing human encroachment. With the need to close facilities, and if exemptions are granted, the public and wildlife will be increasingly exposed to hazardous conditions.

"Senator Gaylord Nelson, the originator of Earth Day, called for a constitutional amendment guaranteeing every American 'an inalienable right to a descent environment." 128 Brazil's Constitution already includes Chapter 6, Article 225, guaranteeing every Brazilian this right. Their less developed military force and more developed environmental constitutional law averts the exemption issue. Although the American military is seeking to reform and scale back operations, perhaps it should accomplish such desires within the existing legislative framework. Is it possible that America can learn from the legislation and values of other countries? If we are courageous enough to do so, then the DOD and conservationist will agree to further their allegedly mutually reinforcing interests with their support for the passage of such a constitutional amendment.

\footnotetext{
${ }^{125} \mathrm{Id}$.

${ }^{126}$ Global Security.org, Environmental Issues, http:/198.65.138.161/military/facility/environment.htm. See Barringer, supra note 122 , for litigation regarding the military and training exercises.

${ }^{127}$ DOD v. ESA, et al., The Environmental Forum, Volume 19, Number 5, Sept-Oct. 2002, at 47.

${ }^{128}$ Nash, Roderick Frazier, Book The Rights of Nature: A History of Environmental Ethics, University of Wisconsin Press (1989) at page 125.
} 
